\title{
EM FOCO \\ HOME PRACTICE: IRISH WOMEN, DIASPORA AND SOMATIC PRINCIPLES OF HOSTING
}

Home Practice: mulHeres

IRLANDESAS, DIÁSPORA E PRINCÍPIOS SOMÁTICOS DE RECEPÇÃO

HOME PRACTICE: MUJERES IRLANDESAS, DIÁSPORA Y PRINCIPIOS SOMÁTICOS DE RECEPCIÓN

\section{EMMA MEEHAN}




\begin{abstract}
In this article, I discuss my exhibition of Home Practice examining matrilineal heritage, which was presented in Manchester in 2016 and 2017. The article unpicks somatic perspectives on cultural embodiment which informed the work, as well ideas of mobile cultural affiliation from Irish Diaspora studies. I explore changing women's roles in Ireland across generations and what the idea of practicing at home might mean in different times and locations, whether through moving, writing, baking, making crafts or hosting events. The latter concept of hosting supported me to engage people with the exhibition, and also stimulated a wider dialogue about migration.
\end{abstract}

RESUMO

Neste artigo analiso minha exposição Home Practice apresentada em Manchester entre 2016 e 2017, onde examino o patrimônio matrilinear. O artigo desvela as perspectivas somáticas sobre corporalização cultural que informaram o trabalho, bem como ideias de afiliação cultural móvel a partir de estudos da diáspora irlandesa. Eu exploro a mudança nos papéis femininos alcançada pelas mulheres na Irlanda, através das gerações e o que a ideia da prática doméstica pode significar em diferentes momentos e locais, seja através da escrita, panificação, confecção de artesanato ou organização de eventos. O conceito de 'recepção' me ajudou a engajar as pessoas na exposição e também estimulou um diálogo mais amplo sobre migração.

\section{RESUMEN}

En este artículo discuto mi exposición Home Practice, que examinó el patrimonio matrilineal y fue presentada en Manchester, entre 2016 y 2017. El artículo desvela perspectivas somáticas sobre la corporeización cultural que informaron el trabajo, así como ideas de filiación cultural móvil a partir de los estudios de la diáspora irlandesa. Exploro el cambio ocurrido en los papeles femeninos alcanzado en Irlanda mediante las generaciones y lo qué la idea de una práctica doméstica puede significar en diferentes momentos y lugares: a través de la escritura, panificación, confección de artesanía u organización de eventos. El concepto de “recepción” me ayudó a involucrar a las personas en la exposición y también estimuló un diálogo más amplio sobre la migración.

\section{KEYWORDS:}

Somatic. Irish. Hosting. Diaspora. Exhibition.
Palavras-chave: Somática. Irlanda. Recepção. Diáspora. Exposição.
Palabras clave: Somática. Irlanda. Recepción. Diáspora. Exposición. 


\section{FOLLOWING A MOVE FROM IRELAND TO ENGLAND}

five years ago, my attention was drawn to the ways in which culture is expressed through the body. I began to wonder: How can somatic movement practices help in understanding the embodiment of cultural heritage? In this article, I explore this question in relation to my piece called Home Practice presented as part of the group exhibition a shrine to women's work (VORIS, 2016a) in Manchester in August 2016. The shrine offered a space to explore and share aspects of my cultural heritage, in particular the idea of 'home practice' linking my creative and familial female lineage. I later re-presented Home Practice at the Theatre and Performance Research Association (TaPRA) Gallery at the University of Salford in August 2017 to further develop methods of “hosting' the exhibit. ${ }^{1}$

Few researchers in somatic practices have dealt in depth with how culture is embodied, or how somatics can be of value in reflecting on migration. Studies about somatic practices could be critiqued for the location of formative historical narratives and descriptions of practice that are largely rooted in America and Britain. Although such scholarship has been ground-breaking as a means of articulating the history and value of somatic work, there is a danger that these narratives could be understood to represent wider world histories and practices of somatics. Sylvie Fortin and Andrée Grau (2014, p. 3) articulate some relevant threads of discussion in the field at the Dance and Somatic Practices Conference 2011, commenting that:

1 In this article, I refer to the exhibited project as Home Practice. I refer to the concept and activity of creative practice in the home more generally without italics as home practice. The idea of home art/practice was first discussed several years ago with Sandra Reeve in a conversation about artists choosing to work in the home in the UK and Ireland. Reeve's reflections were also informed by Javanese movement artist Prapto's "[...] respect for and cultivation of Home Art in Javanese villages so that local practices do not get lost" (personal communication 19 March 2018). 
[...] many felt that it [somatics] had the potential to transcend

these bodies rooted in history, language and culture. Others, however, felt that the narratives used to constitute somatics in different locations or spaces had not been sufficiently articulated.

On the one hand, somatics could raise shared questions across cultures about embodiment, and on the other, there is a need to more fully bring different cultural perspectives into somatic scholarship. Further, to my knowledge migrancy is a topic which has not been rigorously addressed in the field of somatic practices, and one which I am attempting to unravel in this article.

Glenna Batson and Margaret Wilson (2014, p. 74-75) identify qualities of somatic embodiment such as phenomenological knowing and the "[...] capability to intuit, infer, empathize, mimic and be at one with others." In this sense, embodiment unfolds from felt sense experience in relationship to others, relevant to the idea that identity is called into question when changing context and interacting within new social and cultural networks. Martha Eddy (2017, p. 16) defines somatic embodiment in relation to "[...] knowing how to perceive the body, how to stay aware during daily activities, and how to make the connections to derive meaning and purpose from these sensations." Daily encounters shift during migration and can therefore lead to reflections on how identity, home and culture changes when moving country. I build on the theories of these authors to further an understanding of culture as a facet of somatic experience. Practically, I work with two forms of somatic practice called Authentic Movement and Amerta Movement. Authentic Movement, through its attention to sensation, thoughts, feelings, supports methods for tracking cultural embodiment. I draw on practitioners and scholars such as Joan Davis, Eila Goldhahn, and Amy Voris whose work also reflects on creative formats for sharing Authentic Movement practice as well as developing ways of facilitating the relationship between the artworks and the audience - informing the creative practice I describe later. Amerta Movement has been particularly beneficial in helping me to sense my relationship with my environment through developing a responsiveness to where my movement is situated. The work of practitioner-researchers Paula Kramer and Sandra Reeve helps me to describe aspects of Amerta movement embedded in the project, and interrogate context, environment and materials in somatic movement. 
I write as a person coming from Europe, with associated privileges that many

migrants may not have. Karen Barbour (2019, p. 252) notes:

\section{[...] in discussing mobility, I suggest it is important to remember that we may be referring both to those for whom mobility is a choice made as a 'global citizen', and to those for whom mobility is a necessary response to catastrophic local upheaval.}

As a student and worker during the period of the 'Celtic Tiger' financial boom in Ireland, I have had greater access to educational opportunities, work and travel than previous generations of Irish migrants. At the same time, the global recession which hit in 2008 resulted in a further wave of emigration from Ireland, a country which suffered greatly as a small economy reliant on external investment for growth. Likewise, the recent 'Brexit' negotiations of the UK leaving the EU, have compounded feelings of insecurity for Irish immigrants in the United Kingdom, in relation to their rights, national borders, and also attitudes to 'foreign' groups living and working in the area. ${ }^{2}$ Barbour (2019, p. 249) articulates how the "Being 'out of place' as a ‘foreigner' may be unsettling, disorientating and distressing,"

2 See for example Coveney (2018). which is felt due to personally embodied cultural dislocation, and exacerbated by continually shifting contextual and political relationships between nations. My writing aims to start from first person somatic knowledge to point to experiences of cultural difference, colonial histories and the mobility of identities that arise in migrancy. I do not attempt to speak for migrants who move under circumstances of war, disaster or persecution, but my methods try to address wider questions about how somatic practices can help to understand cultural embodiment during migrancy. In the hosting practice described later, I also propose how somatics can support dialogue starting from one's own cultural positioning and extend out to converse and exchange with those from other backgrounds and places.

To develop my arguments in relation to my own cultural positioning, I include literature from the area of Irish diaspora studies, with key authors such as Breda Gray (2004, 2013, 2014), Mary Hickman and D.A.J. MacPherson (2016), and Bronwen Walter (2001) addressing the experiences of women migrants. In research on Irish abroad, “[...] women's experiences remain marginal in many accounts of migration and diaspora" (MACPHERSON; HICKMAN, 2016, p. 1) despite the fact that Irish 
women "[...] emigrated in greater numbers than men in most decades since the mid-nineteenth century." (GRAY, 2004, p. 1) To this field, I add research on Irish women diaspora through creative arts practice integrated with somatic movement theory, which can contribute an understanding of less visible aspects of cultural identity such as the sensed relationship between body and place. Locating this article within diaspora studies “[...] signals relations between 'home' and dispersal, global and intimate scales of belonging, as well as tensions between cultural authenticity and hybridity." (GRAY, 2014, p. 45) Drawing together aspects of Authentic Movement and Amerta movement, I investigate ideas of home-place and cultural mobility that occur in migration through my creative project Home Practice. My hope is that this can lead to a deeper understanding of Irish women's diaspora experience but also offer a space for dialogue across cultures drawing from somatic principles and methods.
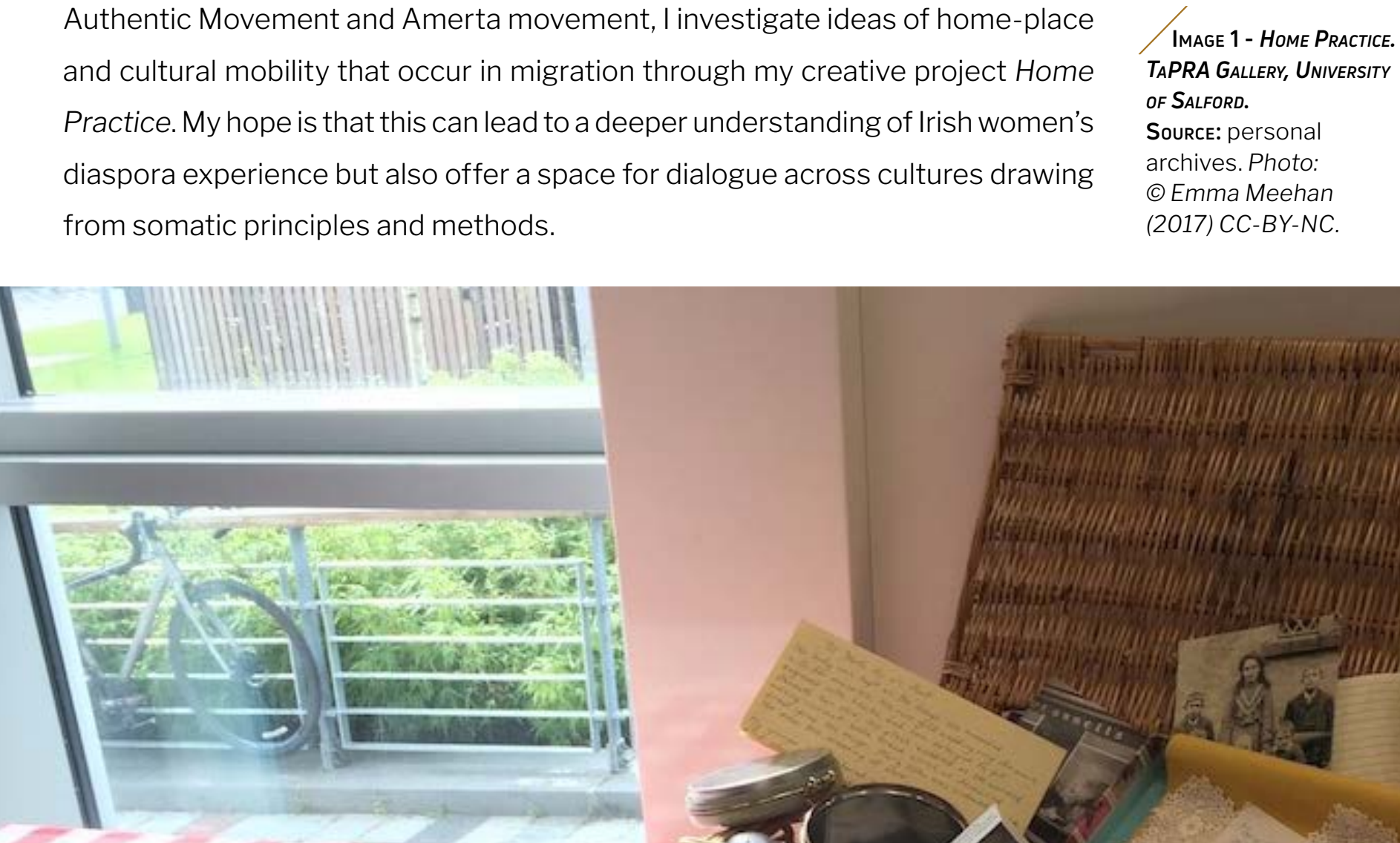


\section{CULTURAL EMBODIMENT AND SOMATIC PRACTICES}

\author{
August 2015: Ecological Body workshop with Sandra Reeve in Sligo, \\ Ireland
}

The workshop is situated in the gardens of a local Irish psychotherapist and movement practitioner Therese O'Driscoll who has invited Sandra Reeve over. To open the workshop, Therese invites us to acknowledge the festival of Lughnasa, of harvest time, and to create a ritual with a potato as we arrive. The instructions are to find a place for the potato within the gardens we are working in. I feel a lack of resonance with this task and connecting to part of an Irish heritage that I never felt related to - pagan rites, rituals and seasons. I look at the potato and see a mock symbol of Irishness, with reminders of the Irish potato famine ${ }^{3}$ but also stereotypes of the Irish diet, and associations of being stuck in the mud, rustic or backward. Wandering in the gardens, I feel out of place, disconnected, lost. Trying to participate in this Lughnasa ritual, I place my potato on a metal seat in the garden. With some frustration building, I rock the seat which holds the potato, creating a loud rattling noise that satisfies my exasperation. The potato rolls around and finds a gap in the metal where it rests. From here, I settle into stillness, looking at the potato wedged in the gap, and ask myself "How can I find my gap, my niche, my place, in between?"

In moving country, I became acutely aware of my own cultural heritage, which to me not only includes cultural works and traditions, but also a set of attitudes, beliefs and behaviours that are passed down across generations. This latter group of embodied inheritances came to my awareness through a range of psychophysical responses to relocating. In England, I felt at times 'out of place' and a need to adapt my ways of relating to others. This began with a familiar flow of habits, which were then interrupted by feelings of disorientation when my expectations for response were not met. For example, I missed the ease with which I got to know new people in Ireland by understanding local codes of forming social groups; I was also aware of differences in use of touch, voice and other interpersonal dynamics in public and private spaces. At other times, I felt distant from Irish cultural customs and
3 Between 1945-1949, The Great Famine took place in Ireland, when the potato crop failed, which resulted in mass starvation and emigration. 
traditions, and unsettled by changes in myself that I noticed through spending

time in England. This account is based in my own personal experience of moving from and to a specific set of circumstances, and I don't want to fall into suggesting stereotypes of Irish or English behaviours. However, awareness of difference and shifts in attitudes or behaviour are likely to be a common thread for those moving country as they embody cultural histories in new communities.

The historical and political relationship between Ireland and England produces its own particular set of issues for Irish migrants. At times, I felt a need to assert my Irish identity, especially to honour the Irish colonial past, which often felt unrecognised. Bronwen Walter (2001, p. 3) notes that “In place of either/or relationships conventionally associated with the resettlement process, migrants and their descendants are connected by both/and ties to their countries of origin and settlement," while “[...] the specificity of the relationship between the Irish diaspora and British imperialism problematises this notion of both/and." This reflects my own feeling of discomfort of developing a new identity informed by both living in Ireland and England, with a need at times to assert my own (and Ireland's) independent identity. Moya Kneafsey and Rosie Cox address Walter's premise that Irish people in Britain become invisible, appearing as an insider but feeling like an outsider, exacerbated by the ways in which the Irish are "[...] incorporated into the myth of 'internal homogeneity' against which black groups are constructed as a new and dangerous presence."4 (KNEAFSEY; COX, 2002, p. 7) At the same time, as mentioned earlier, Brexit has more recently increased uncertainty and fears for Irish immigrants. The complexity of the insider-outsider experience, including a negotiation between the Irish histories which I carry with me and the English context that I live in, have informed a new cultural embodiment in me, and probably countless other Irish immigrants.

In order to investigate somatic embodiment of culture, I draw primarily on the teaching of two somatic practitioners, Irish choreographer Joan Davis and English movement artist Sandra Reeve. Through Davis, I learned to practice Authentic Movement, where a mover learns to cultivate an 'internal witness' where they articulate their own movement process through writing, drawing and speaking. This witnessing process became a foundation for noting my experiences of transitional cultural embodiment as I changed location. The role of context and environment

4 This identification of Irishness with 'whiteness' has been challenged for example by the inclusion of non-white Irish in the 2011 British census, as another group which need to be recognized. (HUTTON, 2012, p. 4) The Association of Mixed Race Irish (2019) was also "set up to positively promote and support Irish people of mixed race backgrounds and their families/ relatives." 
is also a central feature of the work of Sandra Reeve, with whom I studied in both

Ireland and England. Reeve trained extensively in the Amerta movement practice developed by Indonesian artist Suprapto Suryodarmo (also known as Prapto). Like Authentic Movement, Amerta is an improvised exploration often guided lightly through spoken facilitation, however this time with eyes open and with attention in the relationship between the environment and the individual. Reeve has articulated some dynamics and lenses in the work including position, transition, proportion, niche, pattern and emergence. These features of her movement approach informed my somatic exploration when moving to England, particularly around loosening identification with movement habits in order to "[...] lead to a movement, an action that is as appropriate to the context as it is to my personal needs." (REEVE, 2014, p. 69)

What is clear from this brief introduction to my movement lineage from Ireland and England is that each of these practices lead back to more complex cultural roots in America and Asia, which in turn lead back to prior sources. This indicates the complexity of cultural traditions now embodied in my current practice and promotes a more flexible understanding of cultural affiliation. With my move to England, I experienced a sense of identity becoming mobile, with home not experienced in one place. I had split and sometimes conflicting allegiances, in transition between multiple positions. Gray's (2014, p. 46) research on Irish women diaspora also accounts for subjectivities that are “[...] variously complicit, split, ambivalent and actively resistant." Tracking lived experiences through somatic movement practice can bring awareness to structures which have formed identity by revealing movement habits and preferences, in this case culturally inscribed. The value of bringing awareness to habits is to unfix values, belief systems and narratives, and question if these identity stories or behaviours serve the individual in the current environment that they inhabit. It can also offer the opportunity to understand identity as constantly in transition, between self and the environment. How I move includes both my embodied history but also the environment surrounding me. Sights, sounds, smells, textures, structures, pathways and atmospheres shape my movement and change my behaviour; and therefore embodied experience arises from the meeting of self and place. 


\title{
WOMEN'S ROLES AND HOME PRACTICE
}

On moving to England, I started an Authentic Movement exchange with dance artist and scholar Amy Voris. During this time, she co-founded the Accumulations Project, a group of artists concerned with female ancestral lineage in their work. In 2016, the group received Arts Council England funding to generate a series of activities "to explore female genealogies," one of which was a shrine to women's work group exhibition curated by Voris. She notes that:

\begin{abstract}
a shrine to women's work brings together works from eleven artists who have reflected upon matrilineal influences in their own working / playing lives. Such influences include the work / play of mothers, grandmothers and great-grandmothers and also the "grandmothers" of each artist's art form(s) - or artistic lineages... It has arisen from my own feelings of being haunted by the generational differences and resonances between myself and my grandmothers and from my own detailed interest in early modern dance history (my artistic grandmothers). (VORIS, 2016b)
\end{abstract}

Voris' introduction to the project highlights a simultaneous connection to and disconnection from lineage, as she emphasizes a relational enquiry. These are aspects which I also navigate in my submission to the shrine, as investigating cultural heritage can prompt a sense of alignment or separation. Migration especially tests the borders of identity, as the new culture can shift attitudes and behaviour. The shrine project allowed me to assess my relationship with matrilineal heritage just at the moment when I was experiencing a mobility of identities between two cultures.

In preparing for the shrine project, I continued my movement practice and kept journals of the process which include drawings and writing, tracing emerging experiences of cultural embodiment. I also conducted a series of conversations with my father and mother about the women in our families, especially grandmothers and great grandmothers. What emerged was a view of women in Ireland at a moment in time where work opportunities were restricted and bearing children was valorised. 
This is reflected in the Irish constitution of 1937, which states that "The State 2019.1 recognises that by her life within the home, woman gives to the State a support without which the common good cannot be achieved." (IRISH CONSTITUTION, 2018, Article 4.1, 2.1 and 2.2) However, my great grandmothers and grandmothers all found ways to work that were somehow acceptable, such as working in family businesses or making and selling hand-crafts. Most of this work was done in the home between minding children and domestic chores. Hosting people at home, cooking food and baking also were common threads, revealing what seem to be lives of undervalued skill and service to others. Initiatives in the late 1970s around married women working and having access to contraception reflected changing attitudes of the state towards the role of women in Irish society. ${ }^{5}$ By the time my mother married, it was not unusual for women to work outside the home, but they were also expected to be the primary homemakers at the same time.

Through a comparative positioning as suggested by Voris (2016b), I was reminded of the "generational differences and resonances." Unlike the women in my female lineage, I have made choices so far to study, work, not get married and not have children (and of course these choices are also contextually informed). However, I also share interests in baking, hosting, writing and practicing at home - where I do a large portion of my ongoing movement practice. Davis and Reeve, my female creative lineage of teachers mentioned earlier, also practice and present their work in their homes. Davis teaches, performs and holds events in her family property called Gorse Hill in Wicklow, Ireland. Her Maya Lila performances from 2005-2010 regularly took place in her homestead including the sharing of food, performance, artwork and a cultivated garden installation. Reeve also teaches, performs and hosts creative events in her home place called Westhay in Dorset, England, where the sharing of food, conversation, gardens and creativity become central to her open day events. In the past, creative practice in the home has remained unacknowledged as an area of skillful practice. In the work of Davis and Reeve, practice in the home becomes much more publically visible and recognised. Home Practice therefore became the title of my contribution to the shrine and reflected both my familial and creative female lineage.

So far, I have described the idea of home practice in my female cultural and creative lineage, which has proved important to me in relocating. However, there are 
problems with reinforcing the links between woman and home, which for example

the Irish state enshrined as the woman's ascribed place with her role as homemaker. This is an association that has historically restricted women's opportunities for work and therefore often the valuing of their activities financially and socially. Deirdre Heddon (2008, p. 116) identifies the "confining and limiting" aspects of home, as well as questioning the idea that home is a safe space. For many women (and indeed men), the home has been restrictive and sometimes violent, and therefore I don't wish to exalt the position of the home or women's place in it. At the same time, the lack of wider public visibility and valuing of women's work in the home is what I seek to address. The daily activities undertaken in the home by my female ancestors were often highly skilled although behind the scenes, and so to reflect on the validity of home practice seems pertinent. Unlike my female lineage, I have made an active choice to practice in the home, rather than being subjected to it through government or social regulation, and this offers another way to inhabit the home-place. Finola Cronin (2017, p. 51) discusses methods that “[...] reappropriate particular iconic images that associate woman with narratives of Ireland” as “[...] subtle and disruptive strategies that communicate diverse and different accounts of woman in an Irish context." With Home Practice, I wanted to acknowledge the skill of work in the home, find new ways of reappropriating what might be seen as restrictive roles and stage new ways of enacting them.

The exhibited work of Home Practice consists of a picnic hamper which holds a piece of my great grandmother Mary Ellen McGowan's lace, and my mother Anne O'Connell's poem about her. In line with Voris' request to have a relational response, the basket contains a notebook with my own writing from moving with the lace. It also includes an Irish tea brack recipe from my mother, along with a version of the recipe baked by me for sharing with the exhibition attendees. Finally, there are also a series of family photographs, one of which depicts a picnic by the sea with generations of women from my mother's family. The picnic basket became the choice of container for the exhibited objects, serving as reminder of the seaside where I grew up, and also inviting a sense of the sociality of a picnic with others. I hoped the exhibit could invite a dialogue between my own experiences and those visiting, and I envisioned the basket as a starting point for informal sharing with participants, much like a picnic. 

creating. Weaving threads, threads alongside each other, working together, Holding shape, structure, Restricted holding, trapped, But still some gaps, enough space to breathe, The lace teasing in one or other direction. Circles of threads, circling arms, Crumpled lace, resting hands.

\section{Workshop with Suprapto Suryodarmo, UK, June 2016}

Bantham beach looks like the seaside of my childhood, with rough winds and waves crashing on rocks. I reach for my great grandmother's lace, which is in my pocket. As I lift it in my hand, it twirls in the wind, dancing. I place it on my neck. I sit in the passionate weather, as surprising feelings of loss arrive, rising from my chest to my mouth and my eyes. Slowly I fold away the lace and place it back in my pocket.

My emotions ebb away as I feel into the sand with my boots and my hands. I crawl forward like a cat, pushing my claws into the wet and gritty sand. I am reminded of the hands of my ancestors, baking, sewing, washing, taking care. I take some driftwood and slowly walk down the beach to the water's edge. I let the stick float in the water, and wash my hands, letting go of the dance, as I arrive back in this place. ${ }^{6}$

\section{IMAGe 3 - LACE DANCE Bantham Beach, Devon SoURCE: personal archive. Photo: @ Eline Kieft (2016) CC-BY-NC}

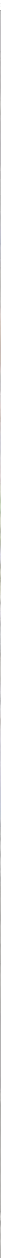




\section{HOSTING DIALOGUE}

TaPRA Gallery, University of Salford, August 2017

I sit on a cushion waiting for the audience to arrive. People wander in, alone or in groups, joining me on the floor. Sometimes I talk a lot, introducing the basket. Other times I invite people to touch, taste, read, smell, And later ask me questions. I notice my fear, a desire to jump out and imagine the needs of others. My breathing goes shallow as I start to 'inform' or 'tell'. As times goes on, I try to breathe deeply and notice the wider space, As I watch for internal and external cues and connections, I hear the stories of the audience of grannies and families, not having children, women's roles, cultural sexuality, migrant journeys.

I was keen to allow for something new to emerge through the encounters between the Home Practice materials and the visitors at the exhibition. This was to incorporate the "multi-perspectived view" in Authentic Movement practice, so that the experience of the exhibit could be "[...] inspired and permeated, nourished and contaminated by a multitude of influences." (GOLDHAHN, 2017, p. 281) Rather than focusing on me as primary meaning-maker of the project, I wished to shift attention towards the relationship between the participants and the sensorial materials in the basket, so guests were invited to play through a written invitation to look, touch, taste, smell, read aloud and so on. Kramer (2015, p. i) also notes the importance of receptivity and exposure to materials in Amerta movement, which she describes as "intermaterial confederations." Bringing together the multi-perspectived view and intermaterial confederations, I envisaged Home Practice as an unfinished encounter between visitors and materials. Aligned with postmodern ideas and practices, I wanted to share the ongoing process and invite others in to reflect on what this might mean for them. 

Although the exhibition format allowed me to point towards the role of materials and audience encounter, I missed my place as embodied enquirer within the exchange. In previous research, I questioned how I might include the openness to relational interaction which is fundamental to the exchange between mover and witness in Authentic Movement, imagining that:

Practice-based research 'offerings' of physical, verbal and written materials could be formulated as an unfinished encounter where potential for interaction is made available in the dialogue between presenter and audience, inviting provocations, uncertainties, moments to respond, questioning, collaborative investigation and curiosity. (MEEHAN, 2015, p. 325-326)

While I could not be at the exhibition all the time, I was in residence at Hope Mill for one day of the two-week run where I met and talked with various attendees. The informal conversations brought to my attention what mattered to those attending, how they viewed their own heritage differently from me but also the value in having space to discuss this with others. In August 2017, one year later, I exhibited Home Practice at the TaPRA conference gallery at University of Salford in Manchester, curated by Alison Matthews. There, I chose to be in the space more often with my exhibition materials, and explore my role in 'hosting' emergent conversations about cultural heritage.

My teacher Joan Davis has investigated the role of the host as a means to explore different ways of integrating the witnessing aspect of Authentic Movement into performances. The host, a role which I had previously played in her work, acted as a guide to the audience through the event and was usually undertaken by someone who had experience of witnessing. In Davis' practice of hosting, she applied British psychoanalyst Wilfred Ruprecht Bion's concept of the 'container.' Bion described the container as the primary relationship of care and receptiveness offered by the mother, and later re-created in therapeutic or other relationships. (CHESSICK, 1993) Further, Davis also incorporated D.W. Winnicott's related idea of 'holding', which originates in the mother's careful physical attention to the baby. (WINNICOTT, 1972) A kind of holding and containment is mediated by the 
presence of the host in Davis' performances, providing attention, care, support, guidance and feedback, that reflect the witnessing process.

Hosting the Home Practice basket also became an important way to mediate complex experiences with others, and to invite clear boundaries around experience. Voris (2017, p. 36) notes that "It is widely regarded that the witness in Authentic Movement practice intends toward a non-judgmental and reflexive attitude of 'holding' which offers the mover space to potentially tolerate a range of emotions and experiences." As the exhibition host, I hoped to hold the space for the audience to engage with the work, to express unformed thoughts and feelings, share them with others, and be open to mingling perspectives. In this context of being hosted, attendees at the exhibition in Salford chose to discuss topics as diverse as choosing not to have children, sexuality in different cultural contexts, and the journeys of migrant grandparents. Here the work extended beyond my own diasporic experiences, opening up shared perspectives on social and cultural identity as well as migration.

Hosting and holding suggests being the stable and secure container for meeting others' needs. Similarly, the role of Irish women being bound to the home was often also connected with being in service to others. Walter (2001, p. 18) notes that:

After the Famine, the Virgin Mary was promoted as a role model for women. Her assigned qualities, which were promoted as ideals for all Irish women, included duty to family, self-sacrifice, submerged sexuality and the elevation of a caring function above all others.

The image of the self-sacrificing and caring woman in the home was a cultural model for women, which could be associated with hosting others. In my shrine contribution, I do not claim to be free from the cultural embodiments of my ancestry. In first attempts at hosting the exhibition, I noticed a tendency to drop my own interests and needs, in order to figure out what attendees wanted, which I associated with an embodied cultural role of women in service to others. Through exploring somatic principles, I feel I have found a way in which this nurturing and holding role can be reappropriated for other purposes. In playing the host, I try to be aware of my own experiences while in the presence of others, much like 
the role of the witness of Authentic Movement practice. I offer containment for conversations by attending to the gestures, comments and queries of attendees, reflecting back their feelings and thoughts, and providing a supportive structure. But I also receive back from the exchange in mutual reciprocity, through a process of posing questions from my own interest, as well as following my own sensations, needs and thoughts. Paradoxically, I wish on the one hand to investigate the skill and craft of hosting which was underestimated in previous generations; and on the other, to move away from women's roles 'in service' towards a negotiation between self and other on a more equal basis. Somatic practices have shifted my cultural embodiment of hosting, as they have brought awareness to patterns of behaviour and opened up new ways of responding.

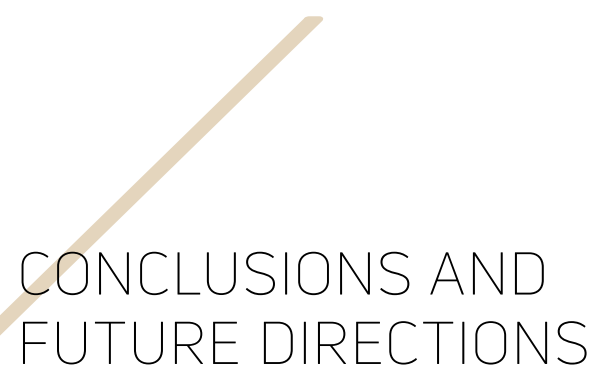

In this article, I have described my own psychophysical disorientation when moving from Ireland to England, in order to examine questions about cultural embodiment in somatic practices. During the process, I have encountered issues such as the historical restrictions of Irish women's role in the home, and further, the invisibility of Irish women in diaspora studies. Through my contribution to the a shrine to women's work, I grew an appreciation of my cultural heritage and the skills of home practice. I investigated the role of host within the exhibition, undertaking the caring role of my creative and cultural lineage, and recognising the potential for reciprocity. Addressing my research question about what somatic practices can offer to understanding cultural heritage, I suggest that they can unpack subtle processes of cultural transmission, revealing genealogies, continuities, crossings, entanglements and dislocations. The project raised questions about definitions of the term home, with both somatic practices and diaspora studies supporting the idea that home is constantly evolving between embodied heritage and places of inhabitation. In my case, a somatic approach offered a way of coming to terms with an emerging fluid identity between two cultures, neither 
one nor the other; while at the same time valuing connections to past cultural history. Further, somatic practices offered the opportunity to assume and adapt inherited behaviours in new ways, altering and expanding cultural embodiment.

While I have focused here on Irish diaspora identity, and noted a critical lack of research about Irish women migrants in Britain, I also suggest there is a value in somatic methods for working with different populations. Somatic practices provide ways for becoming aware of cultural embodiment and a means for exploring the displacement caused by arriving into a new culture. They support the acknowledgement of cultural heritage while allowing adaptations to take place, whether to beliefs, attitudes, feelings or behavior. Sharing my own cultural heritage through the hosting practice also started a dialogue with people from different backgrounds, revealing their cultural experiences, stories, similarities and differences. I have written elsewhere how witnessing involves reflecting on the first person position, in order to “[...] acknowledge subjective perspectives, reflect on personal judgement and develop a form of non-violent communication." (MEEHAN, 2017, p. 233) With the witnessing process incorporated into the hosting role, there is potential for subjective offerings of cultural heritage to open up wider ethical discourses about experiences across cultures. Louise Ryan also calls for comparative analysis of migrant experiences across cultures, in order to gain “[...] a wider understanding of migration processes, experiences and inter-migrant relations, and, secondly, to a fuller appreciation of varied dimensions of migratory experiences in Britain." (RYAN, 2013, p. 6) Hosting offers one practice-based model for this kind of comparative study, inviting participants from different places to track cultural experience and share it in dialogue with others. 


\section{REFERENCES}

ASSOCIATION OF MIXED RACE IRISH. 2019. Available at: www.mixedraceirish.blogspot.co.uk. Access: 9 Feb. 2018.

BARBOUR, K. Dancing in Foreign Places: Practices of Place and Tropophilia. In: HUNTER, V:; BARBOUR, K.; KLOETZEL, M. (ed.). (Re)Positioning Site Dance: Local Acts, Global Perspectives. Bristol: Intellect, 2019.

BATSON, G.; WILSON, M. Body and Mind in Motion: Dance and Neuroscience in Conversation. Chicago: University of Chicago Press, 2014.

CHESSICK, R. A Dictionary for Psychotherapists: Dynamic Concepts in Psychotherapy. London: Jason Aronson, 1993.

COVENEY, S. Brexit must not endanger the Good Friday agreement. Guardian Newspaper, 2018. Available at: <www.theguardian.com/commentisfree/2018/jan/31/brexit-good-fridayagreement-britain-eu-ireland>. Access: 5 Feb. 2018.

CRONIN, F. On Peregrine Collaborations - Cindy Cummings' Choreography of Triúr Ban: Woman, Disorientation, Displacement. In: MEEHAN, E.; MCGRATH. A. (ed.). Dance Matters in Ireland: Contemporary Performance and Practice. Basingstoke: Palgrave Macmillan, 2017.

EDDY, M. Mindful Movement: The Evolution of The Somatic Arts and Conscious Action. Bristol: Intellect, 2017.

FORTIN, S.; GRAU, A. Editorial. Journal of Dance and Somatic Practices, Coventry, v. 6, n. 1, p. 3-7, June 2014.

GOLDHAHN, E. Towards a new ontology and name for 'Authentic Movement.' Journal of Dance and Somatic Practices, Coventry, v. 7, n. 2, p. 273-286, 2017.

GRAY, B. Women and the Irish Diaspora. London: Routledge, 2004.

GRAY, B. 'Generation Emigration': the politics of (trans)national social reproduction in twentyfirst-century Ireland. Irish Studies Review, v. 21, n. 1, p. 20-36, March 2013.

GRAY, B. Thinking Through Transnational Studies, Diaspora Studies and Gender. In:

MACPHERSON, D.; HICKMAN, M. (ed.). Irish diaspora studies and women: theories, concepts and new perspectives. Manchester: Manchester University Press, 2014.

HEDDON, D. Autobiography and Performance. Basingstoke: Palgrave Macmillan, 2008.

HUTTON, S. Irish in Britain Census 2011: The Irish Headlines. 2012. Available in: <www. irishinbritain.org/cmsfiles/Publications/Census-2011-The-Irish-Headlines.pdf>. Access:

2 March 2018.

IRISH CONSTITUTION/ Bunreacht na hEireann. Articles 4.1, 2.1 and 2.2. Dublin: Oifig an tSoláthair,1937, with amendments up to 2018. Available at: www.gov.ie/en/publication/d5bd8cconstitution-of-ireland/. Access: 15 April 2019.

KNEAFSEY, M.; COX, R. Food, gender and Irishness - how Irish women in Coventry make home. Irish Geography, Maynooth, v. 35, n. 1, p. 6-15, 2002. Available at: http://irishgeography.ie/index. php/irishgeography/article/view/243. Access: 16 April 2019. 
KRAMER, P. Dancing materiality: A study of agency and confederations in contemporary outdoor dance practices. 2015. $232 \mathrm{f}$. Thesis (Doctorate in Dance) - Faculty of Arts and Humanities, Coventry University, Coventry, 2015.

HICKMAN, M.; MACPHERSON, D. Introduction: Irish diaspora studies and women: theories, concepts and new perspectives. In: HICKMAN, M.; MACPHERSON, D. Women and Irish diaspora identities: Theories, concepts and new perspectives. Manchester: Manchester University Press, 2016. Project MUSE.

MEEHAN, E. Speak: Authentic Movement, ‘Embodied Text’ and Performance as Research. Journal of Dance and Somatic Practices, Coventry, v. 7, n. 2, p. 313-330, Oct. 2015. Available at: $<$ www.pureportal.coventry.ac.uk/en/publications/speak-authentic-movement-embodied-textand-performance-as-researc-2>. Access: 15 April 2019.

MEEHAN, E. Immersive performance and somatic practices: Joan Davis and the Maya Lila project. Choreographic Practices, London, v. 8, n. 2, p. 219-38. December 2017.

O’CONNELL, A. Til Death Do Us Part. Lancaster: Lancaster University/Poet's House Donegal, 2002. Poem submitted as part of M.A. in Creative Writing.

REEVE, S. The Sacrum and the Sacred: mutual transformation of performer and site through ecological movement in sacred sites. In: WILLIAMSON, A.; BATSON, G. (ed.). Dance, Somatics and Spiritualities: Contemporary Sacred Narratives. Bristol: Intellect, 2014.

RYAN, L. Compare and contrast: understanding Irish migration to Britain in a wider context. Irish Studies Review, v. 21, n. 1, p. 6-19, March 2013.

VORIS, A. Forming, Returning and Deepening: Dance-making with Authentic Movement. 2017. 110 f. Thesis draft (Doctorate in Dance), Department of Dance, University of Chichester, Chichester, 2017.

VORIS, A. a shrine to women's work. Hope Mill, Manchester: AWOL Studios, 2016a. Exhibition. VORIS, A. a shrine to women's work. 2016b. Available at: <www.accumulationsproject.com/ashrine-to-womens-work>. Access: 15 April 2019.

WALTER, B. Outsiders Inside: Whiteness, Place and Irish Women. London: Routledge, 2001.

WINNICOTT, D. The Maturational Processes and the Facilitating Environment: Studies in the Theory of Emotional Development. London: Hogarth Press, 1972. 
Emma Meehan: is Research Fellow/Assistant Professor at Coventry University's Centre for Dance Research, UK. Research interests include somatic practices in different cultural and political contexts, as well as practice as research. She co-edited Dance Matters in Ireland: Contemporary Performance and Practice with Aoife McGrath (Palgrave 2018); and Performing Process; Sharing Dance and Choreographic Process (Intellect 2018) with Hetty Blades. She is Associate Editor for the Journal of Dance and Somatic Practices. She is a researcher on 'Sensing the City: An Embodied Documentation And Mapping Of Urban Place' and lead investigator on 'Somatic practice, chronic pain and self-care technology' both funded by the Arts and Humanities Research Council UK. She has received CONFAP funding to research somatic practices and politics with Prof. Dr. Sergio Andrade at UFRJ in 2020. 